Logos Universality Mentality Education Novelty, Section:

Political Sciences and European Studies

ISSN: 2284 - 5992 (print), ISSN: 2284 - 5992 (electronic)

Covered in: CEEOL, Index Copernicus, Ideas RePeC, EconPapers, Socionet

\title{
THE ELITISM. THEORETICAL AND IDEOLOGICAL CONTRIBUTION TO THE STUDY OF POLITICAL ELITES
}

Anton CARPINSCHI

DOI:

http://dx.doi.org/10.18662/lumenpses.2015.0301.07

Logos Universality Mentality Education Novelty, Section: Political Sciences and European Studies, 2015, Volume III, Issue 1, pp: 93-96

\author{
Published by: \\ Lumen Publishing House \\ On behalf of:
}

Lumen Research Center in Social and Humanistic Sciences 


\title{
The Elitism. Theoretical and Ideological Contribution to the Study of Political Elites
}

\section{Anton CARPINSCHI ${ }^{1}$}

\begin{abstract}
Ciprian Iftimoaei opts for democratic elitism as applicable theoretical approach in solving the controversy between the theory of elites and the theory of democracy, portrayed political elites as "guardians of democracy". In other words, democratic elitism is considered a socio-political approach to (re) reconcile regulatory requirements of democracy (democracy as it should be) with the empirical evidence of the existence of a functioning democracy in elite competitions for exercising political power (democracy as it is).
\end{abstract}

Keywords: elitism, theoretic, ideological contribution, political elites.

${ }^{1}$ Professor Emeritus, “Al. I. Cuza” University of Iasi, Romania.

93

Carpinschi, A. (2015). The Elitism. Theoretical and Ideological Contribution to the Study of Political Elites. Logos Universality Mentality Education Novelty, Section: Political Sciences and European Studies, III(1), 93-96.Doi: http://dx.doi.org/10.18662/lumenpses.2015.0301.07 